\title{
Að lifa í breyttum heimi
}

Á síðustu fjórum áratugum hefur algengi offitu aukist mikið. Árið 2016 áætlaði WHO (Alpjóðaheilbrigðisstofnunin) að $15 \%$ kvenna og $11 \%$ karla í heiminum öllum væru með offitu. ${ }^{1}$ Talið er að um 21\% fullorðinna Íslendinga séu með offitu og að um $60 \%$ séu yfir kjörpyngd.

Með aukinni söfnun fitumassa, sérstaklega í kvið, getur orðið röskun á margvíslegri líkamsstarfsemi eins og pekkt er, með einkennum efnaskiptavillu, virkjun bólguferla, skerðingu á öndun og kæfisvefni, ásamt breytingum á parmaflóru. Pegar ástand er orðið pannig í líkamanum er litið svo á að einstaklingurinn sé kominn með langvinnan efnaskiptasjúkdóm. Vaxandi líkamspyngd veldur einnig auknu álagi á stoðkerfið með langvinnum verkjum. Einstaklingurinn verður pannig fyrir heilsubresti og lífslíkur minnka. Аð auki mætir hann víða fordómum par sem margir telja að sjúkdómurinn sé á ábyrgð einstaklingsins og stafi eingöngu af pví að hans venjur séu ekki góðar og vilji til breytinga sé ekki fyrir hendi. Heilbrigðisstarfsfólk sýnir pví miður of oft peim sem eru með offitu fordóma í stað pess að vinna með vanda skjólstæðingsins. Pessu parf að breyta.

Ástæðan fyrir vaxandi fjölda einstaklinga með offitu eru taldar vera pær miklu pjóðfélagsbreytingar sem orðið hafa pessa sömu undangengna fjóra áratugi. Neyslumynstur hefur breyst mikið, bæði vegna breytinga á leiðbeiningum um heppilegt mataræði, sem settar voru fram í byrjun níunda áratugarins í Bandaríkjunum, og vegna aukinnar iðnvæðingar matvælaframleiðslu. Framboð og neysla hefur aukist á orkupéttum, mikið unnum matvælum með takmarkað næringargildi. Á sama tíma hafa orðið miklar breytingar á daglegum háttum, ferðamáta, streitu og hraða pjóðfélagsins og eðli vinnunnar hefur mikið breyst. Tengsl próunar offitu við áföll á lífsleiðinni eru mjög greinileg.

Margt hefur verið reynt til að stöðva eða hægja á fjölgun einstaklinga í yfirvigt og með offitu en engri pjóð hefur tekist pað. Margvíslegar ráðleggingar hafa verið settar fram og verið sampykktar af alpjóðastofnunum en pað hefur verið tregða hjá stjórnvöldum til að móta stefnu heima fyrir og hrinda breytingum í framkvæmd.

Alpjóðlegir vinnuhópar á vegum tímaritsins Lancet hafa í tvígang, 2011 og 2015, lagt fram viðamikla samantekt með vísindalegri pekkingu um offitu og áhrif sjúkdómsins á heilsufar og efnahag pjóða, ásamt tillögum um aðgerðir. Við endurmat fyrir 2019 var niðurstaðan sú að úrbætur séu óverulegar, pótt nú sé vandinn viðurkenndur á heimsvísu og flestir átti sig á pví að pörf er á aðgerðum. Ákvað vinnuhópurinn pví að nálgast vandann á nýjan hátt og tengja faraldur offitu við faraldur vannæringar og faraldur loftlagsbreytinga sem veldur nú pegar heilsufarslegum vandamálum. ${ }^{2}$ Pessir prír faraldrar spila saman par sem peir gerast á sama tíma, sömu félagslegu hvatarnir knýja pá áfram og peir kalla á sameiginlegar lausnir.

Fjögur meginkerfi knýja pessa faraldra áfram. Раð eru matvælaframleiðsla og landbúnaður, samgöngur, hönnun péttbýlis og landnotkun. Sjúkdómsbyrði í öllum heimshlutum er mest af völdum næringarvandamála og er pá litið til tíðni vannæringar og offitu og algengi neyslu á óheppilegum matvælum. Рað parf að líta á pessa sjúkdóma sem eina heild. Allir eiga peir orsök sína í fæðu með lélegt næringargildi. Ríkar pjóðir eru nú pegar með háa tíðni einstaklinga með offitu og stærra kolefnisspor en fátækari pjóðir. Pegar pjóðir efnast er tilhneiging til vaxandi péttbýlismyndunar og meiri notkunar á vélknúnum farartækjum sem veldur losun gróðurhúsalofttegunda. Mataræði pjóða sem efnast próast yfirleitt í átt að vestrænni matarmenningu, sem veldur meiri losun gróðurhúsalofttegunda, vegna meiri neyslu unninna orkupéttra matvæla og dýraafurða. Matvælaframleiðsla og landbúnaður, sérstaklega framleiðsla á rauðu kjöti og mjólkurafurðum, losar mikið magn gróðurhúsalofttegunda og hefur stórt kolefnisspor. Pegar tekið hefur verið tillit til matarsóunar er losun vegna matvælaframleiðslu lík pví sem er af völdum samgangna. Nú pegar hafa loftlagsbreytingar áhrif á fæðuframleiðslu. Раð eru meiri öfgar í veðurfari en áður, flóð og purrkar sem leiða til endurtekins uppskerubrests með minnkandi fæðuframleiðslu. Fæðuóöryggi fátækari pjóða eykst og matur verður dýrari fyrir alla.

Pví er spáð að ef neysla verður óbreytt, ef við framleiðum og borðum sama magn úr sömu fæðuflokkum og við gerum nú, geti jörðin ekki brauðfætt pá 10 milljarða íbúa sem ætlað er að búi á jörðinni árið 2050. ${ }^{3}$

Við purfum pví öll að hugsa upp á nýtt hvernig lífi við viljum lifa, hvernig við viljum neyta og ferðast til að koma í veg fyrir að heilsufari mannkynsins og jarðarinnar hnigni enn frekar. Læknar eru í góðri stöðu til að láta til sín taka og ráða skjólstæðingum sínum heilt án fordóma.

\section{Heimildir}

1. who.int/news-room/fact-sheets/detail/obesity-and-overweight - apríl 2019 .

2. Swinburn BA, Kraak VI, Allender S, Atkins VJ, Baker PI, Bogard JR, et al. The Global Syndemic of Obesity, Undernutrition, and Climate Change: The Lancet Commission report. Lancet 2019; 393: 791-846.

3. Willett W, Rockström J, Loken B, Springmann M, Lang T, Vermeulen S, et al. Food in the Anthropocene: the EAT-Lancet Commission on healthy diets from sustainable food systems. Lancet 2019; 393: 447-92.

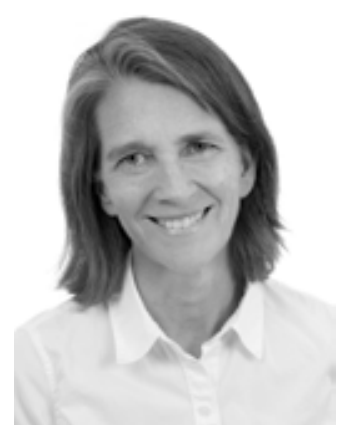

\section{Hildur Thors}

sérfræðingur í heimilislækningum, MPH.

Læknir offituteymis Reykjalundar

hildurth@REYKJALUNDUR.is

\section{To live in a changed world}

Hildur Thors

GP, MPH, Physician at

Reykjalundur Obesity Clinic

doi.org/10.17992/lbl.2019.05.228 